\title{
Spatio-Temporal Change and Driving Force of Oasis for Desert Reservoir from 1988 to 2016 in Northwestern China
}

\author{
Wei Wei ${ }^{1 *}$, Zhenya Li ${ }^{1 * *}$, Binbin Xie ${ }^{2}$, Junju Zhou ${ }^{1}$, Chuanhua $\mathrm{Li}^{1}$ \\ ${ }^{1}$ College of Geography and Environmental Science, Northwest Normal University, Lanzhou, Gansu, China \\ ${ }^{2}$ School of Urban Economics and Tourism Culture, Lanzhou City University, Lanzhou, Gansu, China
}

Received: 11 October 2018

Accepted: 27 November 2018

\begin{abstract}
The interaction and influence mechanism between oasis and desert is an important component of landscape geography in arid areas. The oasis of Hong Yashan Region (OHR) is a typical tail oasis continental river in northwestern China, located in the northern temperate arid desert area belonging to an extremely arid continental climate. In this paper, the spatial distribution information of the oasis in Hong Yashan region was extracted through obtaining remote sensing imagery in 1988, 1992, 1995, 2000, 2004, 2008a, 2013, and 2016. The quantitative models and geographical grid method were used to analyze area changes, direction migrating, intensity fluctuating, and forces driving in order to understand the change mechanism. The results show that during 1988-2016, the oasis area increased first and reached the peak value of $1,343.67 \mathrm{~km}^{2}$ in 2004 , then decreased to the valley value of $1,026.66 \mathrm{~km}^{2}$ in 2008 , and then increased again to $1,077.59 \mathrm{~km}^{2}$ in 2016 . The dominant factors which affected oasis changes were distinct in the different periods and positions, and they interacted with each other. We found that the dynamic changing process of an oasis was the result of natural and human activities. The growth of oasis both in area and distribution have been affected by natural factors through water resource changes.
\end{abstract}

Keywords: arid area, desert reservoir, oasis spatio-temporal evolution, driving forces

\section{Introduction}

Arid and semi-arid regions, where precipitation and water resources are scarce and the ecosystem is bitterly frail and very sensitive to anthropogenic interference, constitute approximately $41 \%$ of the total global land area [1-3]. Besides, about $44.46 \%$ of arid and semi-

*e-mail: weiweigis2006@126.com

**email: 2991180590@qq.com arid regions have seen rising temperatures and reduced precipitation in the past 100 years [4]. Deserts and oases are the main landscapes in the arid and semi-arid regions, with deserts as the landscape matrix, and oases as the landscape mosaic [5-7]. Oases are the foundation of human activities and economic development, supporting more than $95 \%$ of the population in the arid and semi-arid regions of China even though they only occupy less than $5 \%$ of the total area $[3,8]$. An oasis not only provides valuable fertile soil and living space for human beings in the barren desert, but also adjusts 
the regional climate by the vegetation and water resources within it. Thence, the oasis ecosystem diametrically affects the environmental and social safety in arid and semi-arid regions. The oasis dynamic has been one of the critical topics of concern in recent decades $[9,10]$.

An oasis is defined as an efficient eco-geographical landscape that allows flourishing vegetation or human settlement due to a stable water supply [11]. It is the unique synthesis that combines nature with artificiality and impacted by long-term human activities [12-14]. The oasis dynamic has deeply influenced natural landscapes through a combination of natural, aquatic and sociocultural factors, and this issue has received worldwide attention since the mid-1990s [15].

At present, research related to the oasis dynamic have focused on four respects: analyzing the law of land use change in the oasis region [16-20], discerning the connection between oasis dynamic and water resources $[10,21,22]$, evaluating the ecological effects of oasis dynamics [10, 23], and discussing the appropriate scale of an oasis [11, 24]. Generally, the oasis dynamic has been researched through analysis of the oasis dynamic in land use type of the oasis, such as cultivated field, forestry, territorial waters, and grassland [15]. However, at the scale of the whole arid and semi-arid region, an oasis could be considered as a unitary geographical landscape [15]. So far, few studies have treated the oasis as a single geographic landscape unit and the spatiotemporal evolution of most oases was studied with a single method.

Hong Yashan Reservoir is the largest artificial desert reservoir in Asia. In this paper, the oasis of Hong Yashan Region (OHR), a representative oasis in the lower reaches of Hong Yashan Reservoir, was selected as a case study for oasis dynamics. We regarded the oasis as a single landscape and used multiple methods to verify the oasis dynamic over a long-term time scale. The analysis was conducted in the context of social factors related to oasis change between 1988 and 2016. Specifically, the purposes of this article were to: (1) examine the spatial-temporal patterns of OHR changes from 1988 to 2016; (2) determine the influence factors of oasis change dynamics; and (3) discuss feasible strategies for the sustainable development of the oasis.

\section{Material and Methods}

\section{Study Area}

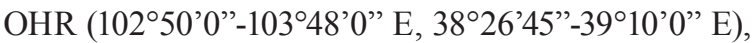
situated downstream from Shiyang River Basin (SRB) in northwestern China (Fig. 1), belongs to the cross belt of the Chinese Eastern Monsoon Region, Qinghai-Tibetan Alpine Region with dry climate [25]. The precipitation is about $115 \mathrm{~mm}$ per year and is mainly concentrated in July to September, while the potential evaporation is about 2,644 $\mathrm{mm}$ per year. The OHR occupied the area

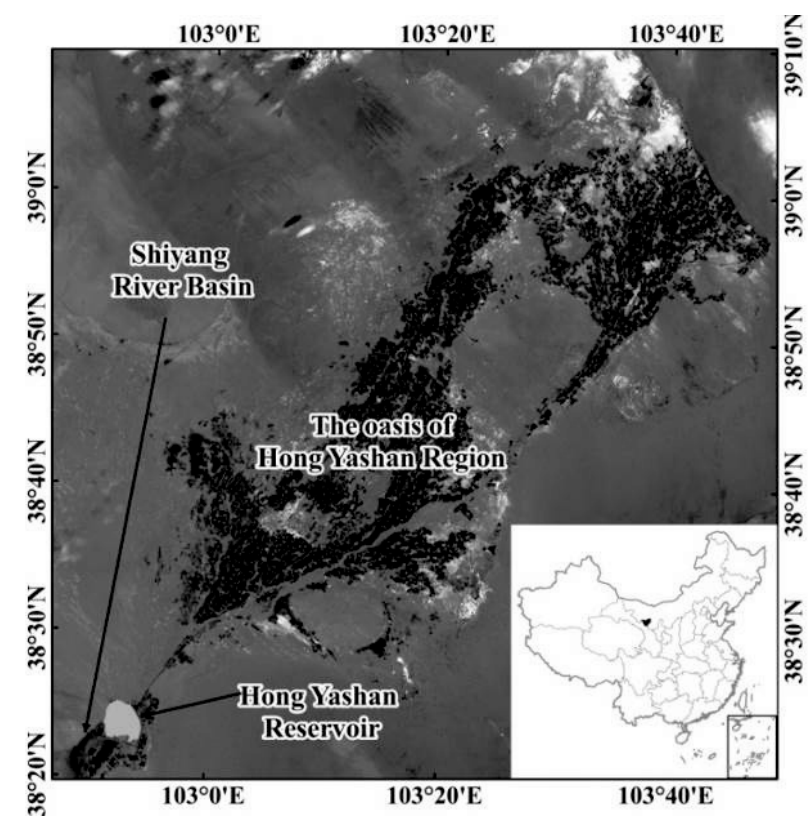

Fig. 1. Location of Minqin oasis.

of $1,139.33 \mathrm{~km}^{2}$ and included 18 townships, such as the Daba, Caiqi, Changning, Datan, Dongba, Donghu, Nanhu, Quanshan, Sanlei, etc, with a total population of 273,700 , the agricultural population accounted for $82 \%$ of the population in 2016. The main vegetation types were crop lands, such as wheat, corn, cotton, etc.

\section{Data Sources and Processing}

The data in this paper include:

(1) Landsat TM/OLI images of OHR from June 16, 1988 July 29, 1992, July 06, 1995, July 19, 2000, July 30, 2004, July 25, 2008, June 05, 2013, and July 31, 2016 (spatial resolution is $30 \mathrm{~m} \times 30 \mathrm{~m}$ ) obtained from NASA (https:// www.nasa.gov/). These data were of high quality and in the oasis change-sensitive period can meet the needs of this study. These data were selected in summer and/or autumn, because this period is the best time to research the oasis.

(2) 1988 to 2016 socio-economic data, including population, agricultural population, crop planting structure, crop area, and GDP, came from the socioeconomic statistical yearbook provided by Minqin Bureau of Statistics.

(3) Yearly runoff data of Shiyang River from 1988 to 2016 came from the Minqin County Water Administration Bureau.

(4) Precipitation and evaporation data of OHR from 1988 to 2016 came from the China Meteorological Data Sharing Service System (http://cdc.cma.gov.cn/home.do).

Before the information extraction, the image needs to be preprocessed, including radiometric calibration, atmospheric correction, geometric correction, and cropping. In this study, land use and land cover of OHR were divided into four categories by a contemporary machine-learning classier using maximum likelihood 
method: unused, oasis, reservoir, river and canal. After accuracy verification, Kappa coefficient is above 0.86 in order to meet research needs.

\section{Study Methods}

\section{Oasis Dynamic Detection Methods}

Oasis dynamic change was characterized by the area of annual variation [26] and bidirectional dynamic degree of the oasis [27], and the status, trend and direction of the oasis were analyzed using LUCC models [28]. The mathematical expressions were as follows:

$$
\begin{gathered}
S_{y}=\frac{1}{T}\left(S_{l}-S_{i}\right) \\
C_{b}=\left(\left(\left(\frac{\Delta \mathrm{S}_{\text {in }}+\Delta S_{\text {out }}}{S_{i}}+1\right)^{1 / T}\right)-1\right) \times 100 \% \\
C_{s}=\frac{\Delta S_{\text {in }}-\Delta S_{\text {out }}}{\Delta S_{\text {in }}+\Delta S_{\text {out }}}
\end{gathered}
$$

...where $S_{y}$ and $C_{b}$ were defined as the area of annual variation and dynamic degree of the oasis; $S_{l}$ and $S_{i}$ represented the oasis area at the last and the initial stage of a time period, respectively, while $\Delta S_{\text {in }}$ and $\Delta S_{\text {out }}$ represented the oasis gain and loss, respectively; $T$ was the length of study period. $C_{s}$ was defined to characterize the overall status and trend in oasis and $-\leq C \leq 1$, when $-1 \leq C_{s}<0$, the oasis is in the state of "expansion"; when $0<C_{s} \leq 1$, the oasis is in the state of "shrinking". The information about $C_{s}$ could be found in Luo et al. [28].

\section{Spatial Orthocenter Transfer Model}

We used the spatial orthocenter transfer model to measure transfer distance and the direction of the oasis orthocenter in order to quantify spatiotemporal variations of the oasis $[29,30]$. The model was shown as follows:

$$
\begin{gathered}
X=\frac{\sum_{i=1}^{n} x_{i} w_{i}}{\sum_{i=1}^{n} w_{i}} \\
Y=\frac{\sum_{i=1}^{n} y_{i} w_{i}}{\sum_{i=1}^{n} w_{i}}
\end{gathered}
$$

...where $X$ and $Y$ is the orthocenter coordinate of the oasis; $x_{i}$ and $y_{i}$ are the coordinates of the i-th oasis patch; and $W_{i}$ is the each patch area of oasis.

\section{Oasis Change Pattern Analysis}

A grid is an effective method to break through the limits of administrative boundaries and spatially expresses the variability of an oasis [31]. It can reflect the spatial change of an oasis in detail grid by grid through raster data format. In this paper, the study area was divided into $100 \times 100 \mathrm{~m}$ equal-sized grid elements to compare their spatial differences in different periods. At the same time, the spatial data of the study area will be encoded with 1 for an oasis grid and 0 for a nonoasis grid, which will be calculated within each study period through the change of the unit grid oasis area. And the intensity of the oasis change is represented by the frequency of the oasis grid change. Similarly, on the same grid element, the intensity change of many years of sample oasis is expressed by grid cumulative change rate $(G C C)$. The mathematical expression was shown as follows:

$$
G C C=\sum_{i=1}^{n-1}\left|C_{l}-C_{i}\right|
$$

...where GCC is the rate of grid cumulative change; $n$ is the number of oasis sample year; and $C_{l}$ and $C_{i}$ represented the oasis code at the last and initial stages of a time period.

\section{Oasis Change Partition Method}

To better understand the changes of OHR, we combine the coding method, mathematical arrangement and integrated algorithm to obtain a total number of different codes. The mathematical statistical methods was used to summarize the patterns that can reflect the basic characteristics of the temporal and spatial changes of the oasis, and then the method of layer separation was used to separate oases into different types. After summarizing, the oasis model division standard (Table 1) was formulated. According to the division standard, the OHR of 1986-2016 was classified into seven types: (1) stable; (2) pre-stable zone; (3) late stable zone; (4) stage stable zone; (5) fluctuation zone; (6) short-lived; and (7) newly emerged.

\section{Results}

\section{Quantity Change Characteristics of OHR}

The area change of oasis during the period of 1988-2016 is shown in Fig. 2a) and the rate of year change is shown in Fig. 2b). Oasis-desert conversion area of different periods is shown in Fig. 2c). Although the area change of OHR fluctuated over time, the oasis change can be divided into three phases from 1988 to 2016: $1988-2004$ and 2008-2016 were the oasis expansion period, while 2004-2008 was the oasis retreat period. During the period of 1988-2004, the oasis area grew rapidly and the conversion area from desert 
Table 1. Oasis model division standard.

\begin{tabular}{|c|c|c|c|}
\hline $\begin{array}{l}\text { Change } \\
\text { mode }\end{array}$ & & Multiple coding & Oasis State Description \\
\hline Stable & 01111111, & $\begin{array}{l}\text { 10111111, 11011111, 11101111, 11110111, } 11111011, \\
\text { 11111101, 11111110, } 11111111\end{array}$ & $\begin{array}{l}\text { Occurrence frequency of oasis appears } \\
\text { more than seven times }\end{array}$ \\
\hline \multirow{3}{*}{$\begin{array}{l}\text { Basically } \\
\text { stable }\end{array}$} & Pre-stability & $\begin{array}{c}11110000,11110001,11110010,11110100,11110011 \\
11110101,11110110,11111000,11111001,11111010 \\
11111011,11111100\end{array}$ & $\begin{array}{l}\text { Oasis continuously appear more than four } \\
\text { times since beginning }\end{array}$ \\
\hline & Late stability & $\begin{array}{c}\text { 00001111, 10001111, 01001111, 00101111, 01101111, } \\
\text { 10101111, 11001111, 00011111, 10011111, 01011111, } \\
\text { 11011111, 00111111 }\end{array}$ & $\begin{array}{c}\text { From the end of the period, there are more } \\
\text { than four consecutive oasis }\end{array}$ \\
\hline & $\begin{array}{l}\text { Stage } \\
\text { stability }\end{array}$ & $\begin{array}{c}\text { 01111000, 01111001, 01111010, 01111011, 00111100, } \\
\text { 00111101, 00011110, 10111100, 10111101, 10011110, } \\
\text { 11011110, 01111100, 01111101, 00111110, 10111110, } \\
01011110,01111110\end{array}$ & $\begin{array}{c}\text { There are four or more consecutive oasis, } \\
\text { but not in the beginning or end }\end{array}$ \\
\hline Fluctuation & \multicolumn{2}{|c|}{$\begin{array}{c}11010000,11001000,11000100,11000010,11000001,10110000, \\
10101000,10100100,10100010,10100001,10011000,10001100, \\
10000110,10000011,10011000,10001100,10000110,01101000, \\
01100100,01100010,01100001,01011000,01010100,01010010, \\
01010001,01001100,01000110,01000011,00110100,00110010, \\
00110001,00101100,00101010,00101001,00100110,00100011, \\
00011010,00011001,00010110,00010101,00010011,00001011, \\
10100000,10010000,10001000,10000100,10000010,01010000, \\
01001000,01000100,01000010,01000001,00101000,00100100, \\
00100010,00100001,00010100,00010001,00001010,00001001, \\
00000101 \ldots\end{array}$} & $\begin{array}{l}\text { The oasis has continuously appeared less } \\
\text { than three times, and the non-oasis state is } \\
\text { more than two times }\end{array}$ \\
\hline Short-lived & \multicolumn{2}{|c|}{$\begin{array}{c}00000010,00000100,00001000,00010000,00100000,01000000 \\
10000000,00001100,00000110,00011000,00110000,01100000 \\
11000000\end{array}$} & Oasis no more than two times \\
\hline $\begin{array}{l}\text { Newly } \\
\text { emerged }\end{array}$ & \multicolumn{2}{|r|}{00000011,00000001} & Appeared in the last three years \\
\hline
\end{tabular}

to oasis was greater than that from oasis to desert, the region is dominated by oasisization. From 1988 to 2004 , the increased area of oasis was $183.84 \mathrm{~km}^{2}$, and the annual average increased area was about $11.49 \mathrm{~km}^{2}$. From 2004 to 2008 , the decreased area of oasis was $317.01 \mathrm{~km}^{2}$, and the annual average decreased area was $79.25 \mathrm{~km}^{2}$. From 2008 to 2016, the increased area of oasis was $50.93 \mathrm{~km}^{2}$, the annual average increased area was about $6.37 \mathrm{~km}^{2}$, which indicated that the oasis area fluctuated change during the whole study period, but its variation range gradually decreased and the area gradually stabilized recently. During the period of 2008-2016, the annual area of oasis began to increase again. During the period of 1988-2004, the conversion area from desert to oasis was greater than that from oasis to desert, the region was dominated by oasisization (Fig. 2c), but it was dominated by desertification from 2004. After 2008, the oasis area was dominated by oasisization again.

The bidirectional dynamic degree of the OHR change and the trend of the oasis area between oasis and desert was calculated using Eqs. (2) and (3) and their long-term variations were summarized in Fig. 2d) and 2e), respectively. Overall, the bidirectional dynamic degree experienced a process of "decrease-increasedecrease" (Fig. 2d). During the period of 1988-2004 and
2008-2016 there were the bidirectional dynamic degree decrease periods, while it was the bidirectional dynamic degree increase period from 2004-2008. During the whole period of 1988-2016, the state and tendency of the oasis were fluctuant and unbalanced, manifesting as stable increased-decreased sharply-increased slowly (Fig. 2e).

\section{Spatial Change Characteristics of OHR}

\section{Spatial Distribution of OHR}

Fig. 3 shows the spatio-temporal distribution of oasis changes during the whole period from 1988 to 2016, when it was found that the increased area mainly distributed the outside of original oasis, especially south of the OHR from 1988 to 2004, which indicated that the water source in Hong Yashan Reservoir was the main force. However, the oasis region undergoes about a five-year decrease from 2004 to 2008 , which mainly concentrated in the north of the oasis far from the core region. After 2008, the oasis in the transition zone of the desert-oasis in the southwest continued to be reduced, while in the middle and northeast it was expanded because of the ecological water transport start from 2006. 

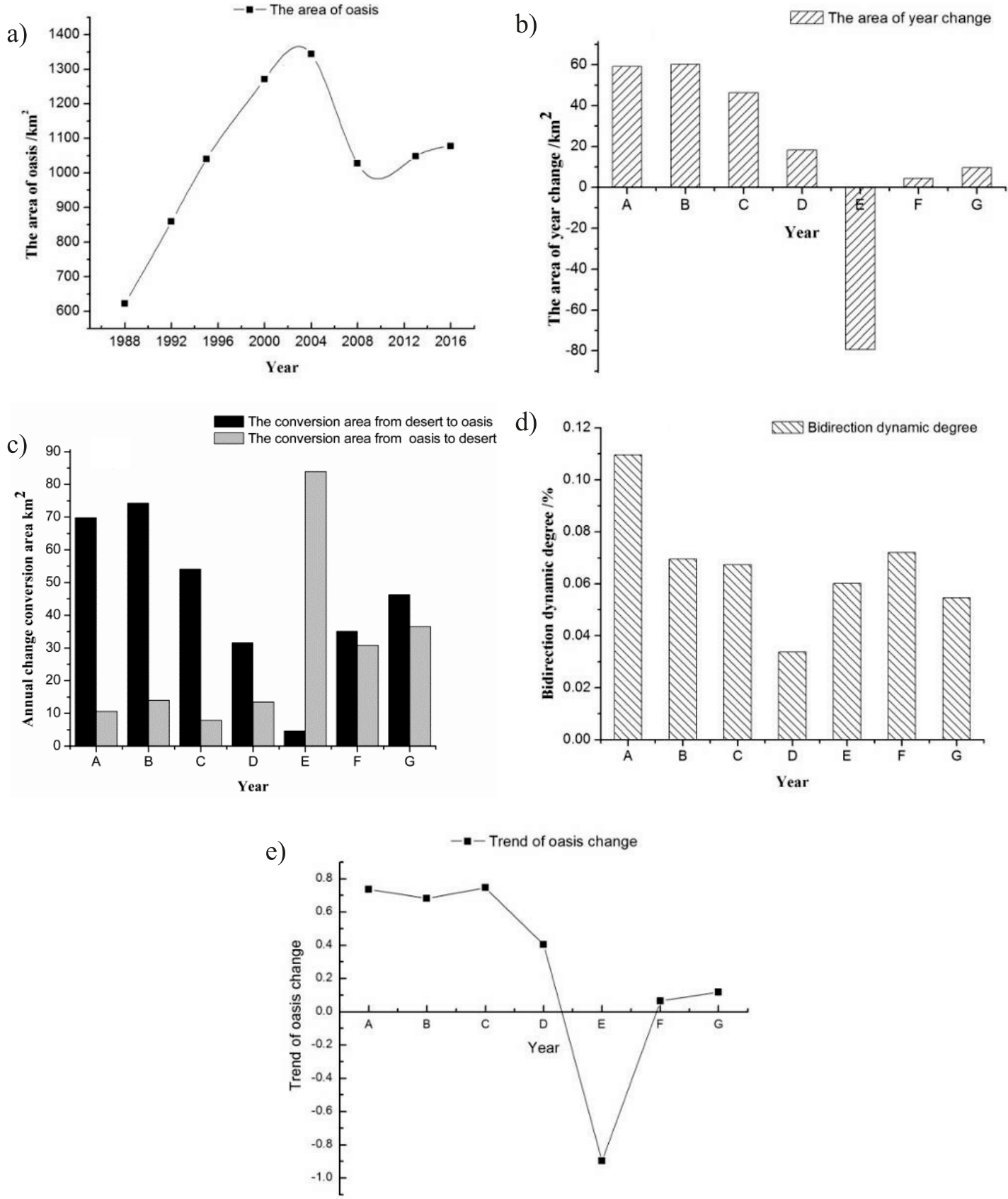

Fig. 2. The dynamic degree and trend of OHR from 1988 to 2016 (A:1988-1992; B:1992-1995; C:1995-2000; D: 2000-2004; E: 2004-2008; F: 2008-2013; G: 2013-2016.)

\section{Changed Direction Analysis of OHR}

The oasis migratory direction was calculated using the spatial gravity transfer model, which is expressed through Eqs. (5) and (6). Fig. 4 shows that in the whole period of 1988a-2016a, the migration center moved southwest first, and then moved northeast. In the southwest, the farthest point appeared in 1995, 3.66 kilometers from the original point in 1988, and 4.35 kilometers from the southern point in 2016.

Seen from the perspective of orthocenter migration, we found that the expansion and contraction of the oasis were mainly concentrated in the southwest, east and northeast. In the northeast direction, there were bare soil, desert, bare rock and other non-oasis components in the oasis area and the margin of the oasis, which indicated that the natural evolution of the local ecological environment was relatively frequent from 1988 to 2016. In addition, after 2000, the Chinese government has implemented large-scale ecological governance such as ecological water transport, afforestation, desertification prevention and other measures in the OHR. The gravity center transferred to downstream of Hong Yashan Reservoir because of the beneficial human measures. 

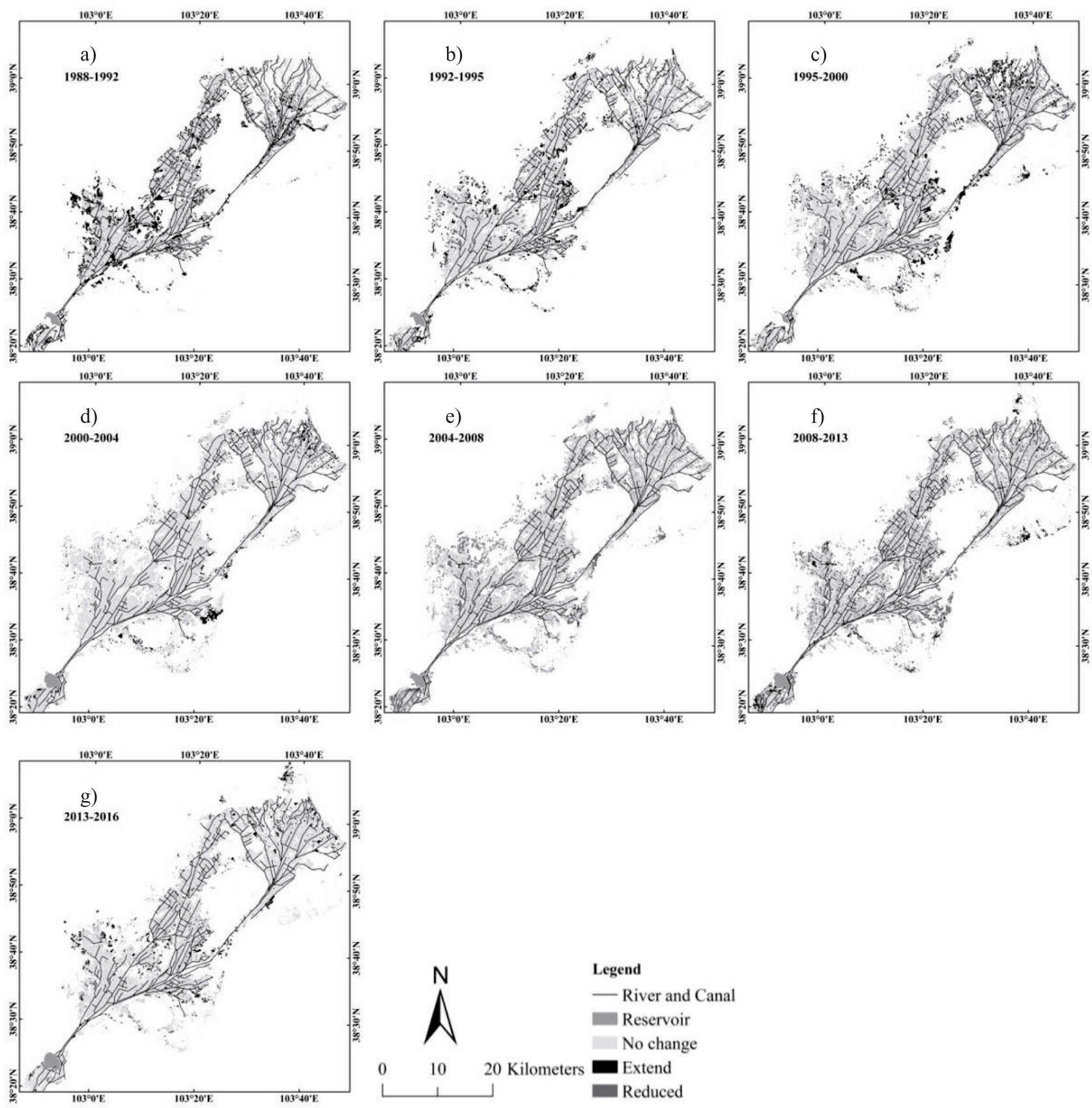

Fig. 3. Spatio-temporal dynamic and evolution of oasis spatial distribution.

\section{Grid Cumulative Change Rate (GCC) Analysis}

The cumulative change rate of oasis can reflect frequency of oasis increase or decrease through each grid, which can better understand the change characteristics of oasis in each period. In this study, we calculated seven research stages (A: 19881992; B: 1992-1995; C: 1995-2000; D: 2000-2004; E: 2004-2008; F: 2008-2013; G: 2013-2016) respectively. Fig. 5 reflected the cumulative frequency of oasis changes in the study area during the whole change period. Number 1 represented the region where the oasis changed only once in the seven study stages, number 2 represented the changed twice, and similarly, number 7 represented the oasis changed 7 times (changes occurred in each period). It was found that 1 or 2 times were the main change frequency, and the changed area was also larger than 3 to 7 times. The result showed that the area changed once was $295.13 \mathrm{~km}^{2}$, which accounted for $25.90 \%$ of the total area of OHR, while area changed twice was $389.26 \mathrm{~km}^{2}$, accounting for $34.17 \%$ of the total area (Table 2). In contrast, three to seven times changes of oasis were less than once and twice changes. In addition, the change occurred both inside and outside of the oasis, with the characteristic of sporadic and disordered distribution. Overall, changed frequency was relatively disorderly, which reflected how oasisization 


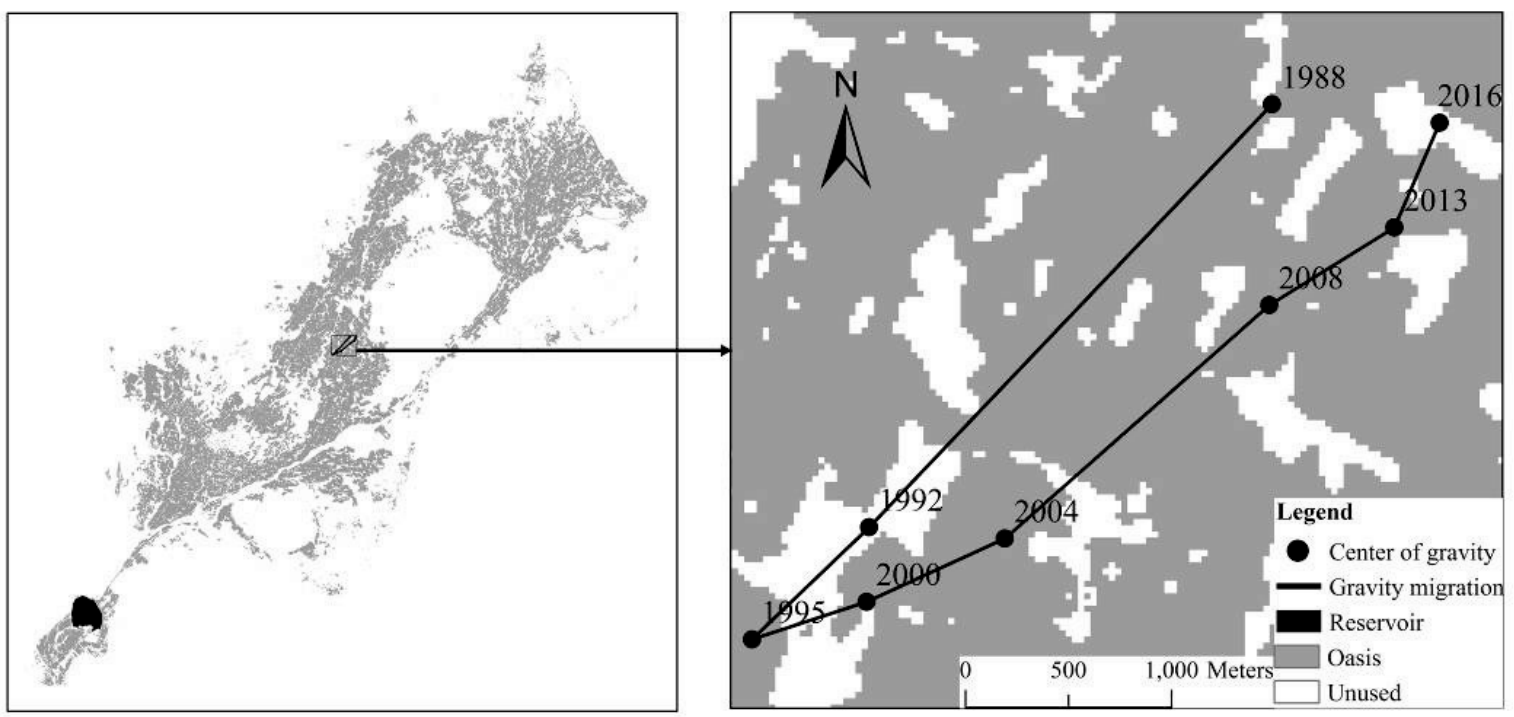

Fig. 4. Direction migration of oasis.

and non-oasisization were simultaneously evoluted because of changes in the natural environment.

\section{Oasis Change Partition Analysis}

After converting oasis data into raster data, the changed frequency and time were computed according to the oasis change partition method and oasis encoding method, and the whole change characteristics were divided into seven partitions, including: stable, prestable, late stable, stage stable, fluctuation, short-lived and newly emerged, and the partition map was displayed in Fig. 7. The stable oasis zone is mainly distributed in the oasis interior, where it had relatively abundant water sources from the Shiyang River and Hong Yashan Reservoir. The pre-stable zone is distributed at the edge of the oasis in the southwest, while the late stable zone is located in the northeast. In addition, the fluctuation zone, short-lived zone and newly emerged

Table 2. Area statistics of grid cumulative change frequency in study area.

\begin{tabular}{|c|c|c|}
\hline Change frequency & Area $\left(\mathrm{km}^{2}\right)$ & Ratio (\%) \\
\hline 0 & 204.72 & 17.96 \\
\hline 1 & 295.13 & 25.90 \\
\hline 2 & 389.26 & 34.16 \\
\hline 3 & 167.34 & 14.68 \\
\hline 4 & 66.49 & 5.83 \\
\hline 5 & 12.65 & 1.11 \\
\hline 6 & 3.64 & 0.31 \\
\hline 7 & 0.10 & 0.008 \\
\hline Total & 1139.33 & 100.00 \\
\hline
\end{tabular}

zone were scattered and irregular distribution in the marginal region. The area of each partition was also calculated according to the map (Table 3), and we found that the area of short-lived was the largest in the seven partitions, which accounted for $21.37 \%$ of the total area of OHR, while newly emerged was the least, which was only $32.77 \mathrm{~km}^{2}$, accounted for $2.88 \%$ of the total area. It indicated that the OHR was stable from the whole study period, although the area increased or decreased in different steps, and spatial changed in the ecological frangible region.

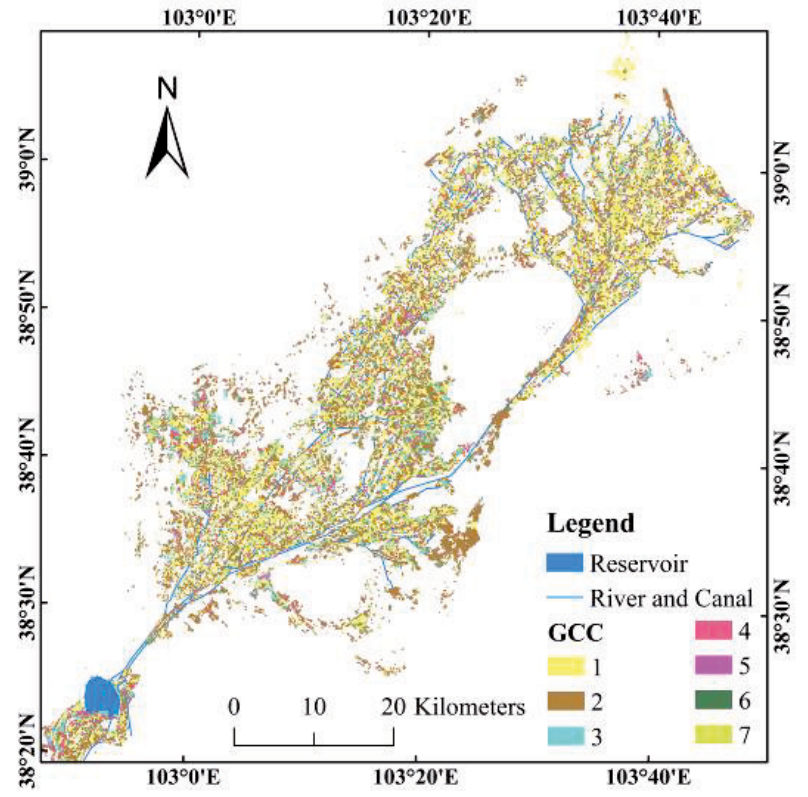

Fig. 5. Cumulative rate of 1988-2016 oasis dynamic. 


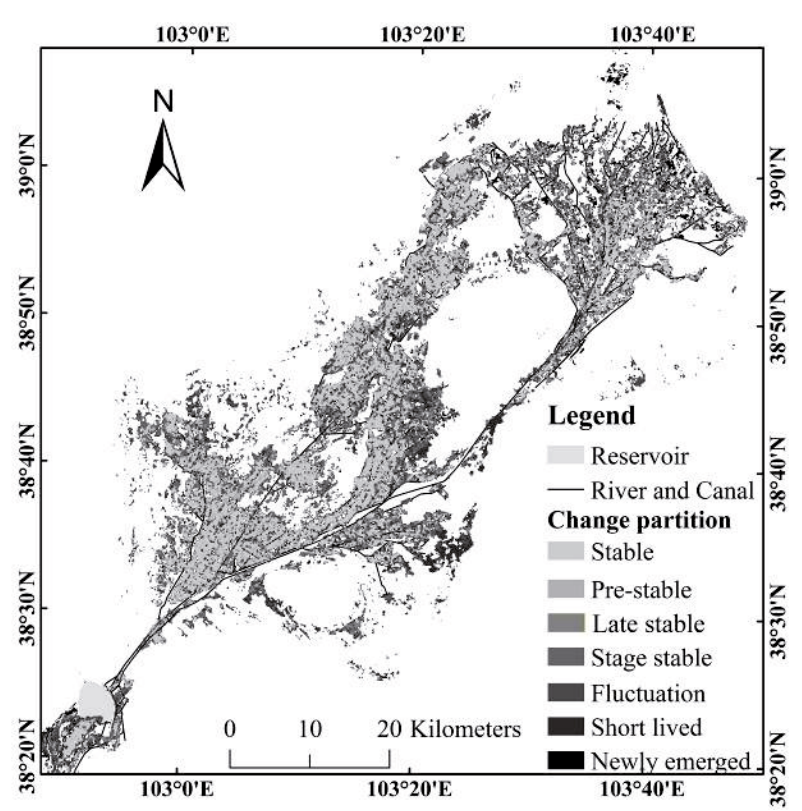

Fig. 6. Oasis change partition map of OHR.

Table 3. Area statistics of oasis change partition map of OHR.

\begin{tabular}{|c|c|c|}
\hline Partition & Area $\left(\mathrm{km}^{2}\right)$ & Ratio (\%) \\
\hline Pre-stable & 52.34 & 4.59 \\
\hline Late stable & 115.01 & 10.09 \\
\hline Newly emerged & 32.77 & 2.88 \\
\hline Short-lived & 243.46 & 21.37 \\
\hline Stable & 371.49 & 32.61 \\
\hline Stage stable & 128.28 & 11.26 \\
\hline Fluctuation & 195.98 & 17.20 \\
\hline Total & 1139.33 & 100.00 \\
\hline
\end{tabular}

\section{Discussion}

\section{Major Driving Forces of the Oasis Change}

\section{Water Resources Driving Force}

Water is the basis for the development and stability of the oasis in the arid and semi-arid region, and it is one of the most active factors for the local natural environment [32]. Because water-supply of the oasis water source mainly comes from precipitation, river runoff surface water, and groundwater [33], water resources and water environment changes have become the main driving force for the oasis change. The availability of water resources directly affected the scale and distribution of the oasis [34, 35].

OHR is located in the northwest inland area, precipitation is very low (130 $\mathrm{mm}$ per year) (Fig. 7a), and it mainly concentrates in summer; in contrast, evaporation is very strong $(2,500 \mathrm{~mm}$ per year)

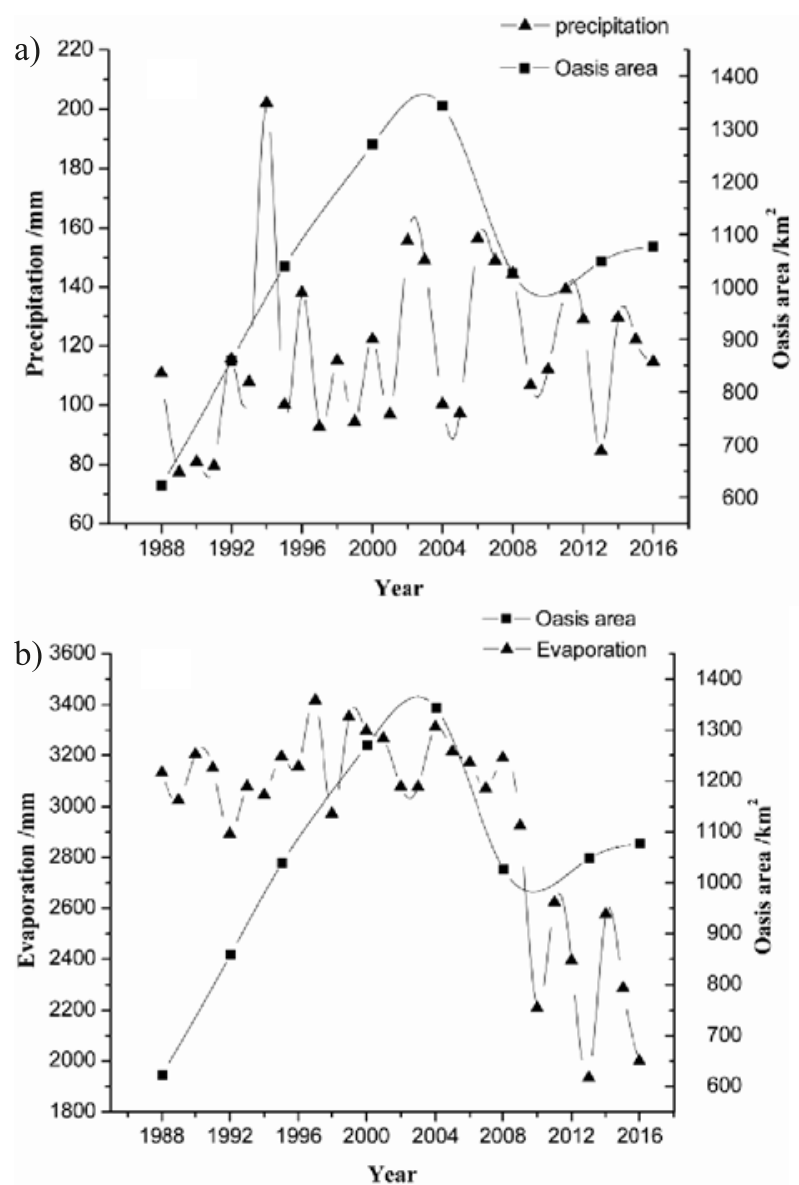

Fig. 7. Change of precipitation and evaporation in OHR from 1988 to 2016.

from 1988 to 2016 (Fig. 7b) [36, 37]. The amount of evaporation is far higher than precipitation, but the oasis has a trend of slowly expanding. The expansion of the oasis area is bound to consume a large amount of surface water and groundwater, which was mainly pumped and irrigated through drilling wells. As a result, the groundwater level in the region has dropped significantly and the ecological environment has deteriorated further.

The surface water resources in the OHR mainly include the upstream water flow of the SRB and the water storage of the Hong Yashan Reservoir, which was also the main water resource for the whole downstream oasis. In this paper, remote sensing images were used to calculate the area of Hong Yashan Reservoir from 1988 to 2016 (Fig. 8a). The results showed that the area of Hong Yashan Reservoir showed a fluctuating increase trend (Fig. 8b). The water storage of the reservoir showed a decreasing trend during the period of 1988-2002 (Fig. 8c), but it obviously increased after 2002. The change in its storage capacity was closely related to the upstream water inflow (Fig. 8d). As the upstream water inflow increased, the reservoir could store the excess water for industrial, agricultural and living water of the middle and lower reaches. 
Groundwater is the main source for oasis irrigation in the arid and semi-arid region, and plays an important role in the change of the OHR [38-40]. Groundwater resources are mainly used through the number of pumped wells to supply the needs of the oasis. The number of wells first increased and then decreased during the study period and reached the maximum value of 9,718 in 2004 (Fig. 8e). After 2004, the number of wells decreased year by year - especially the number of pumped wells decreasing from 9,718 in 2004 to 8,866 in 2008, and about 2,323 pumped wells were closed by the government after 2004 in order to protect the groundwater and improve the eco-environment. The total volume of groundwater was extracted about 600 million $\mathrm{m}^{3} /$ year after 2000 , but the groundwater recharge was only 176 million $\mathrm{m}^{3} /$ year $[41,42]$. Although the amount of groundwater extracted gradually decreased after 2004 (Fig. 8f), the groundwater table in the Hong Yashan Region continued to decline after 2006 $[43,44]$, which indicated that OHR has become one of the most overexploited regions in terms of groundwater depletion around the world [45].

In general, the oasis changes in Hong Yashan have different driving forces in different periods. From the results we found that before 2004, groundwater dominated and surface water was used as supplemental water, but after 2004 the amount of groundwater pumping was gradually reduced, and the water source was mainly surface water, supplemented by groundwater. During the period of 1988-2004, although a)

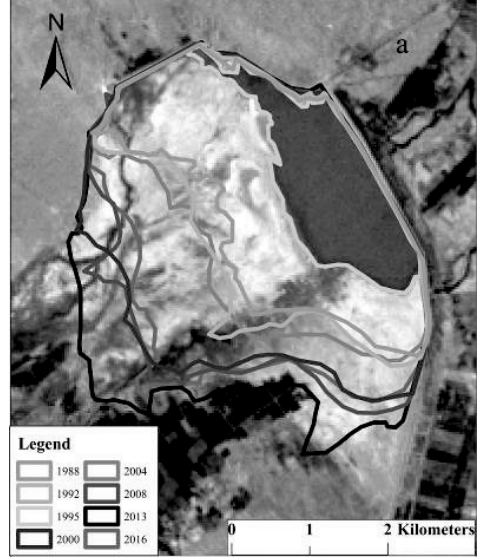

c)

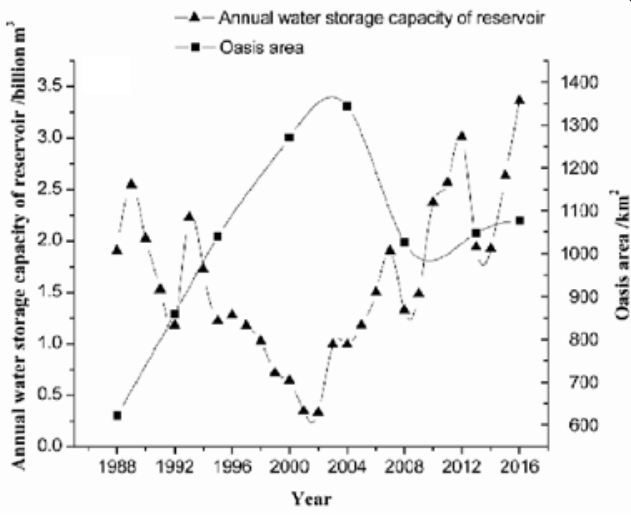

e)

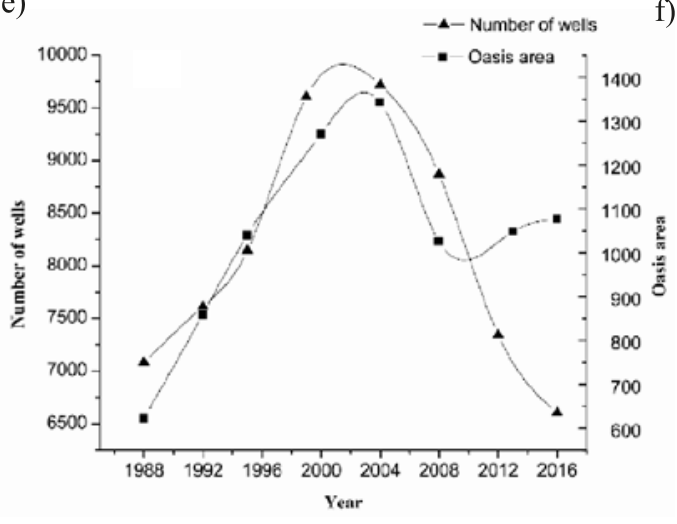

d) b)
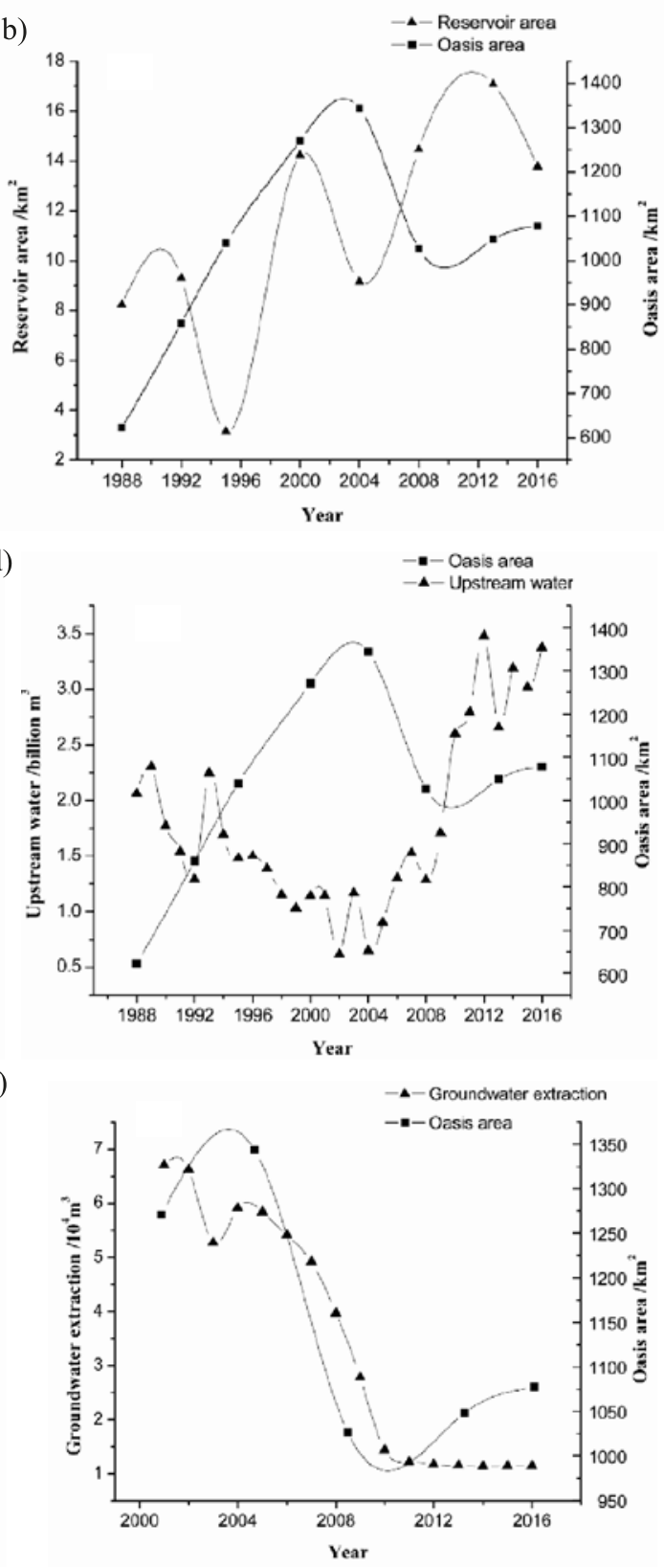

Fig. 8. Variation of upstream water volume, annual water storage capacity of reservoir, number of wells, groundwater extraction, reservoir area and reservoir boundary in OHR from 1988 to 2016. 

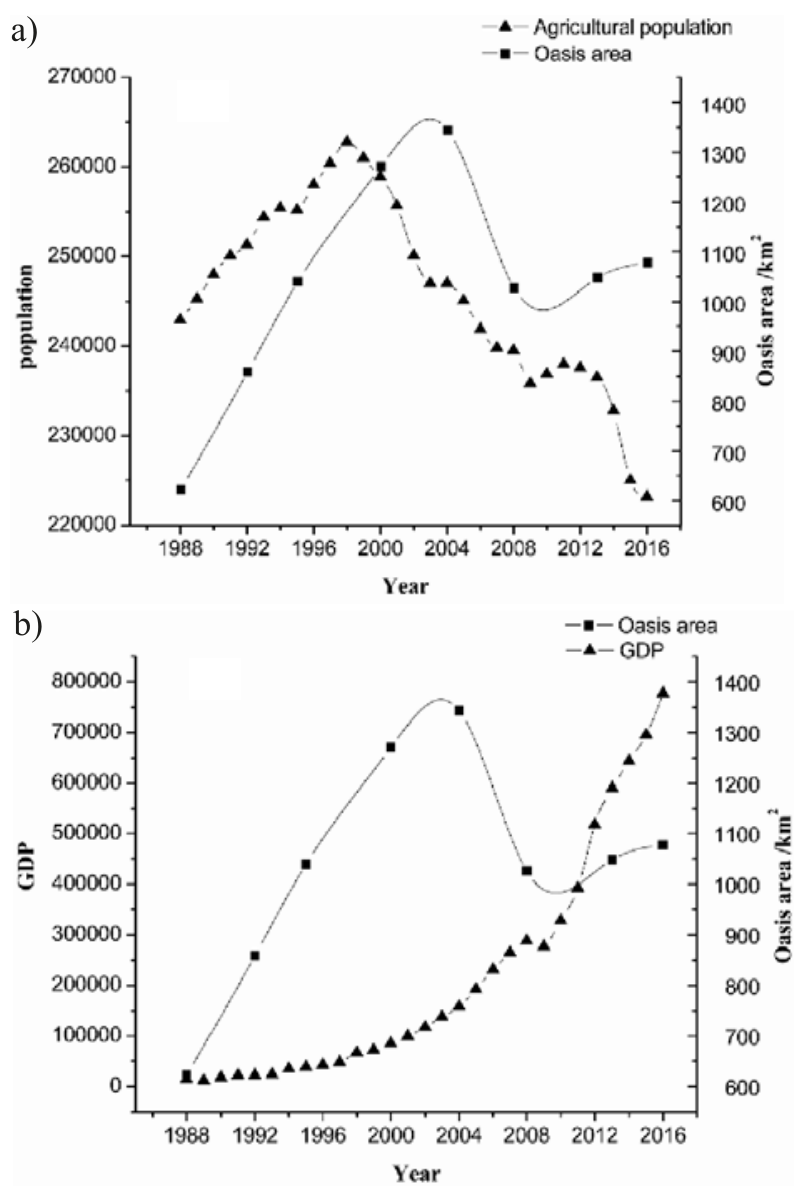

Fig. 9. Change of human population and GDP in OHR from 1988 to 2016 . surface water continued to decrease, the area of oasis still increased due to the continuous increase in the amount of groundwater extracted. During the period of 2004-2008, due to reduced groundwater withdrawal and less surface runoff, the oasis area began to shrink. After 2008, the surface water volume continued to increase, and the oasis area began to increase steadily.

\section{Social and Economic Driving Force}

Oasis expansion often correlates with an increase in human population [15]. Population growth has been considered to be one of the major factor leading to the change of oasis land cover [46, 47]. In the period of 1988-1998, the agriculture population (a population living in rural areas or market towns) increased from 242,900 to 262,800 , and the oasis area increased from $622.31 \mathrm{~km}^{2}$ in 1988 to $1,343.67 \mathrm{~km}^{2}$ in 2004 (Fig. 9a). Moreover, the agriculture population started decreasing after 1998 - from 262,800 to 239,500 during the period of 1998-2008, and the oasis area decreased from1, $343.67 \mathrm{~km}^{2}$ to $1,026.66 \mathrm{~km}^{2}$ during the period of 2004-2008. Seen from the change regularity, we found that the relationship between population and oasis area of OHR was close.

In general, due to the increased population, the natural resources such as food and land supply would increase correspondingly, which promoted the expansion of an oasis in a certain period of time. Moreover, migrants were another main driving force of the oasis expansion, especially in the arid inland river basin in Gansu Province. Economic development also plays an important role in oasis change [15]. Oasis area

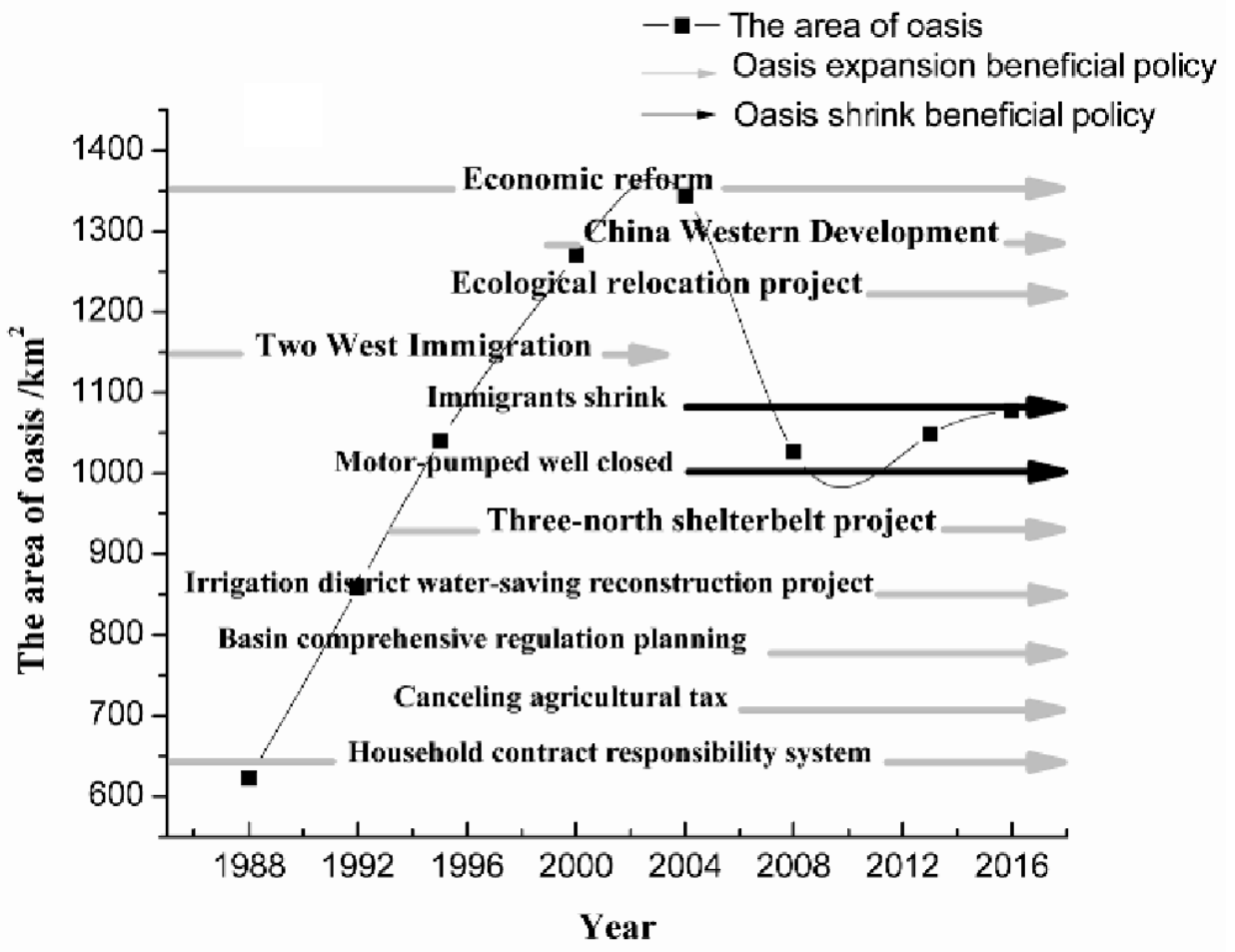

Fig.10. Major policy forces for and against oasis expansion in Hong Yashan region from 1988 to 2016. 
gradually increases with the increase of GDP (Fig. 9b) under certain conditions of productivity and production levels. For farmers, the best way expanded the area of farmland and increased crops. For example, from the 1980s to the mid-1990s, affected by the market demand of black melon seeds [48], farmers of OHR adjusted their planting structure and increased the area of black melon seeds, which directly led to the expansion of the oasis.

Policies, such as China's economic reforms policy and country development strategies, also play an important role in the area change and sustainability of OHR (Fig. 10) [15]. The effect of policy and institutional change on land use change is prominent $[49,50]$. Land is the foundation of farmers' survival and economic benefits source. If there was no restriction of any conditions, farmers would inevitably adopt the way of expanding the arable land area to improve their living standards and oasis area will also change. Policy has directive and mandatory function for the oasis change. In the 1980s, the Household Production Responsibility System and Migration Project were promulgated by the Chinese government. Consequently, a large area of the wasted land and grassland was reclaimed. After 2004a, such policies reduced the number of immigrants and closed the motor-pumped wells, leading to a decrease of the OHR area. After 2005a, China Western Development, Ecological Planning of Shiyang River had a profound impact on the regional ecological sustainable development of OHR [51]. As a result, policy was a complex factor that not only influenced oasis area change, but also forced various changes that both threatened or promoted oasis sustainable development [15].

\section{Implication for Ecological Management and Application in Arid Areas}

Our study found that OHR expansion was mainly concentrated in the ecotone between oasis and desert, which was typical for most of the oases in the arid and semi-arid region of northwest China, such as oasis in Manas River Valley [41], and the oases of the Sangong River Watershed [28]. This will be some significant implications for the ecological and sustainable development in the arid and semi-arid region. Due to the interactive influence of various kinds of natural conditions and human activities involved, it was difficult to reach an agreement on the causes and processes of oasis change at the level of regional landscapes [52]. Our study also found that the dominant driving factors of oasis changes were also distinct in different periods and positions, and they often interacted with each other. In addition, population factors and government policy were responsible for the change of OHR, and the water resources utilization was the main driving factor, which was similar to the results of oasis change in other arid and semi-arid regions, such as Chyulu Hills squatters, Kenya [53], Northern afar rangelands, Ethiopia [54] and also most regions in northwestern China. This means that in arid and semi-arid regions, ecologically sensitive and fragile areas tend to concentrate on the transition zone between oases, especially artificial oasis and desert, which are significantly affected by natural conditions and human activities. If the oasis area is expanded along the transition zone through planting the drought-resistant crops, community afforestation can markedly reduce the degree of desertification. On the contrary, it can significantly promote expansion of desertification, which seriously effects the local socialeconomic dynamic and its sustainable development.

Rapid population growth and excessive utilization of natural resources since the 1980s have damaged the ecoenvironment of the Hong Yashan region. The area of natural oasis has been decreasing and oasis sustainable development has been restricted severely. In order to promote the scientific development of OHR, some measures should be taken and proposed in this paper:

(1) Improving water use efficiency by increasing watersaving agriculture and recycling industrial and municipal wastewater. At present, most of the OHR has used drip irrigation technology, which could solve the problems mentioned above.

(2) Building all kinds of water conservancy facilities, such as reservoirs and aqueducts, to improve the capacity of water storage. Rainwater, snow melt water and other unutilized water resources should be stored.

(3) The current agricultural structure should be changed, and low-yield, high-water crops should be phased out and replaced with less-water crops. At present, the crops in OHR are mainly corn, sunflower, melon, fruit and flowers, which all consume large amounts of water. On the contrary, grapes, nursery stock and tourism trees should be vigorously promoted in the future.

(4) Increase farmer incomes by means of vocational skills training and labor export in order to reduce the economic pressure caused by changes in planting structure.

(5) The local government should strengthen cooperation with universities and scientific research institutions to apply the latest scientific research results to the process of promoting the sustainable development of oasis.

\section{Conclusions}

This study showed that remote sensing data could be used to monitor oasis change over a long-term period, like the monitoring of LUCC in other areas. This way made the change research at a larger spatial scale and a longer duration possible. We monitored the spatialtemporal dynamic changes of oases for the last 30 years in the reserve by applying images of seven phases. This changed markedly at the spatial and temporal scale with the frequent and drastic conversion between oasis and desert from 1988 to 2016. The results showed that the oasis area reached the maximum value of $1,343.67 \mathrm{~km}^{2}$ in $2004 \mathrm{a}$, and then decreased to 
the minimum value of $1,026.66 \mathrm{~km}^{2}$ in 2008 , and then increased again to $1,077.59 \mathrm{~km}^{2}$ in 2016 . The main change area was concentrated in the oasis-desert interlocked belt and the area where human activities were frequent. The dominant factors that affected oasis changes were distinct in the different periods and positions, and they interacted with each other. We found that the dynamic changing process of the oasis was the result of natural and human activities. The growth of oasis both in area and distribution have been affected by natural factors through water resource changes. However, artificial oases had been significantly altered by human activities and social factors such as water source management policies, engineering measures for ecological protection and water-saving projects.

In addition, this paper regards the oasis as a single landscape and does not consider the internal structure of the oasis. That is to say, the land use types such as land for construction, cultivated land, forest land, and water are not considered in the process of analysis. Besides, oasis change was a complex and gradual process in arid and semiarid China. The interactions between oasis and desert changes and how to quantify and develop comprehensive, representative parameters to describe spatio-temporal patterns were not analyzed in this paper. Understanding the oasis change and its landscape effect for the catchment was the basis for sustainable management and development of oasis. In the future, more attention should be paid to the change mechanism and the interactions between oasis and desert in an arid region.

\section{Acknowledgements}

We gratefully acknowledge the support for this research by the National Natural Science Foundation of China (Nos. 41861040 and 41761047); the Natural Science Foundation of Gansu Province (No. 1506RJZA129); and the Research Capability Improvement Program for Young Teachers of Northwest Normal University (No. SKQNYB14032).

\section{Conflict of Interest}

The authors declare no conflict of interest.

\section{References}

1. BRINK A.B., BODART C., BRODSKY L., DEFOURNEY P., ERNST C., DONNEY F., ANDREA L., TUCKOVA $\mathrm{K}$. Anthropogenic pressure in East Africa: monitoring 20 years of land cover changes by means of medium resolution satellite data. Int. J. Appl. Earth. Observ. Geoinf. 28, 60, 2014.

2. REYNOLDS J.F., ET AL. Global desertification: building a science for dryland development. Sci. 316 (5826), 847, 2007.
3. LI X., YANG K., ZHOU Y.Z. Progress in the study of oasis-desert interactions. Agric. For. Meteorol. 230, 2016.

4. HUANG J.P., GUAN X.D.F. Enhanced cold-season warming in semi-arid regions. Atmos. Chem. Phys. 12 (12), 4627, 2012.

5. CHENG G.D., ET AL. Integrated study of the waterecosystem-economy in the Heihe River Basin. Natl. Sci. Rev. 1 (3), 413, 2014.

6. XU L., ZHOU H., PAN F., WU L., TANG Y. Spatial variability of precipitation for mountain-oasis-desert system in the Sangong River Basin. Acta. Geogr. Sin. 71 (5), 731, 2016.

7. FU Q., LI B., HOU Y., BI X., ZHANG X. Effects of land use and climate change on ecosystem services in central Asia's arid regions: a case study in Altay Prefecture, China. Sci. Total. Environ. 607 (2017), 633, 2017.

8. WANG J.M., WANG W.Z., LIU S.M., MA M.G., LI X. The problems of surface energy balance closure: an overview and case study. Adv. Earth. Sci. 24 (7), 705, 2009.

9. CHENG W.M., ZHOU C.H., LIU H.J., ZHANG Y., JIANG Y., ZHANG Y.C., YAO Y.H. The oasis expansion and ecoenvironment change over the last 50 years in Manas River Valley, Xinjiang. Sci. China. Ser. B. 49 (2), 163, 2006.

10. SONG W., ZHANG Y. Expansion of agricultural oasis in the Heihe River Basin of China: Patterns, reasons and policy implications. Phys. Chem. Earth. 89 (7), 46, 2015.

11. LING H.B., XU H.L., FU J.Y., FAN Z.L., XU X.W. Suitable oasis scale in a typical continental river basin in an arid region of China: A case study of the Manas River Basin. Quatern. Int. 286 (430), 116, 2013.

12. SU Y.Z., ZHAO W.Z., SU P.X., ZHANG Z.H., WANG T., RAM R. Ecological effects of desertification control and desertified land reclamation in an oasis-desert ecotone in an arid region: a case study in Hexi Corridor, northwest China. Ecol. Eng. 29 (2), 117, 2007.

13. LIU B., ZHAO W.Z., CHANG X.X., LI S.B., ZHANG Z.H., DU M.W. Water requirements and stability of oasis ecosystem in arid region, China. Environ. Earth. Sci. 59 (6), 1235, 2010a.

14. LIU Y.X., ZHANG X.L., LEI J., ZHU L. Urban expansion of oasis cities between 1990 and 2007 in Xinjiang China. Int. J. Sust. Dev. World. 17 (3), 253, 2010b.

15. XIE Y.C., GONG J., SUN P., GOU X.H. Oasis dynamic change and its influence on landscape pattern on Jinta oasis in arid China from 1963a to 2010a: Integration of multi-source satellite images. Int. J. Appl. Earth. Observ. Geoinf. 33 (12), 181, 2014.

16. BAI J., CHEN X., LI L., LUO G., YU Q. Quantifying the contributions of agricultural oasis expansion, management practices and climate change to net primary production and evapotranspiration in croplands in arid northwest China. J. Arid. Environ. 100 (1), 31, 2014.

17. GUO M., YU W. B., MA M.G., LI X. Study on the oasis landscape fragmentation in northwestern China by using remote sensing data and GIS: a case study of Jinta oasis. Environ. Geol. 54 (3), 629, 2008.

18. ZUBAIDA M., XIA J.X., POLAT M., SHI Q.D., ZHANG R. Spatiotemporal changes of land use/cover from 1995 to 2015 in an oasis in the middle reaches of the Keriya River, southern Tarim Basin, Northwest China. Catena. 171 (2018), 416, 2018.

19. HU N.K., LI X. Spatial distribution of an ancient agricultural oasis in Juyan, northwestern China. Front. Earth. Sci.-Prc. 8 (3), 338, 2014.

20. WANG Y., GAO J.X., WANG J.S., QIU J. Value assessment of ecosystem services in nature reserves in 
Ningxia, China: a response to ecological restoration. PloS. One. 9 (2), 2014.

21. MISAK R.F., BAKI A.A.A., EIHAKIM M.S. On the causes and control of the waterlogging phenomenon, Siwa Oasis, northern Western Desert, Egypt. J. Arid. Environ. 37 (1), 23, 1997.

22. SIEBERT S., NAGIEB M., BUERKERT A. Climate and irrigation water use of a mountain oasis in northern Oman. Agric. Water. Manage. 89 (1), 1, 2007.

23. ZHANG X.F., ZHANG L.H., HE C.S., LI J.L., JIANG Y.W., MA L.B. Quantifying the impacts of land use/land cover change on groundwater depletion in Northwestern China - a case study of the Dunhuang oasis. Agric. Water. Manage. 146 (146), 270, 2014.

24. LEI Y., LI X.Q., LING H.B. Model for calculating suitable scales of oases in a Continental river basin located in an extremely arid region, China. Environ. Earth. Sci. 73 (2015), 571, 2015.

25. XIE Y.W., B, Q., H, C.S. Human settlement and changes in the distribution of river systems in the Minqin Basin over the past 2000 years in Northwest China. Eco. Health. Sustain. 3 (11), 1401011, 2017.

26. PONTIUS JR., R.G., SHUSAS E., MCEACHERN M. Detecting important categorical land changes while accounting for persistence. Agric. Ecosyst. Environ. 101 (2), 251, 2004

27. SETO K.C., FRAGKIA M. Quantifying spatiotemporal patterns of urban land-use change in four cities of China with time series landscape metrics. Landsc. Ecol. 20 (7), $871,2005$.

28. LUO G.P., ZHOU C.H., CHEN X. A methodology of characterizing status and trend of land changes in oases: a case study of Sangong River watershed, Xinjiang, China. J. Environ. Manage. 88 (4), 775, 2008.

29. OKORUWA A.A., TERZA J.V., NOURSE H.O. Estimating patronization shares for urban retail centers: an extension of the Poisson gravity model. J. Urban. Econ. 24 (3), 241, 1988.

30. LIU Y.Q., SONG W., DENG X.Z. Understanding the spatiotemporal variation of urban land expansion in oasis cities by integrating remote sensing and multidimensional DPSIR-based indicators. Ecol Indic. https:// doi.org/10.1016/j.ecolind. 029. 01.2018.

31. WEI J.J., XIE Y.W. The hexi area oasis extraction method and spatial distribution based on remote sensing. D. Lanzhou. Univ, Lanzhou, 2016.

32. ALAM K. Farmers' adaptation to water scarcity in drought-prone environments: a case study of Rajshahi District, Bangladesh. Agric. Water. Manage. 148 (2015), 196, 2015.

33. LING H.B., XU H.L., QIAO M., FAN Z.L., SHI W., ZHANG Q.Q. Temporal-spatial evolution of stream construction and its driving forces in Manas River Basin during 1958-2006. J. Prog. Phys. Geog. 29 (9), 1129, 2010.

34. JIA B.Q., ZHANG Z.Q., CI L.J., REN Y.P., PAN B.R., ZHANG, Z. Oasis land use dynamics and its influence on the oasis environment in Xinjiang, China. J. Arid Environ. 56 (1), 11, 2004.

35. LI X.L., TONG L., NIU J., KANG S.Z., DU T.S., LI S, DING R.S. Spatio-temporal distribution of irrigation water productivity and its driving factors for cereal crops in Hexi Corridor, Northwest China. J. Agr. Water. Manage. 179 (2017), 55, 2017.

36. QIN J., LIU Y., CHANG Y., LIU S.W., PU H.Z. Regional runoff variation and its response to climate change and human activities in Northwest China. Environ. EarthSci. 75 (20), 1366, 2016.

37. LI Z.X., FENG Q., WANG Q.J., KONG Y.L., CHENG A.F., YONG, S., LI Y.G., LI J.G., GUO X.Y. Contributions of local terrestrial evaporation and transpiration to precipitation using $\delta 180$ and $\mathrm{D}$-excess as a proxy in Shiyang inland river basin in China. Global. Planet. change. 146 (2016), 140, 2016.

38. YIN S., CHEN J., WU K.S., Y, X. Adaptation of farming households under drought stress: based on a survey in the Minqin Oasis. Progr. Geogr. 35 (5), 644, 2016.

39. FENG S.Y., HUO Z.L., KANG S.Z., TANG Z.J., WANG F.X. Groundwater simulation using a numerical model under different water resources management scenarios in an arid region of China. J. Environ. Earth. Sci. 62, 961, 2011.

40. LI X.Y., XIAO D.N., HE X.Y., CHEN W., SONG D.M. Dynamics of typical agricultural Landscape and its relationship with water resource in inland Shiyang River watershed, Gansu province, northwest China. J. Environ. Monit. Assess. 123, 199, 2006.

41. ZHANG Y.L., MA J.H., CHANG X.L., WONDEREN J.V., YAN L.L., HAN J.H. Water resources assessment in the Minqin Basin: an arid inland river basin under intensive irrigation in northwest China. J. Environ. Earth Sci. 65 (6), 253, 2012.

42. HAO Y.Y., XIE Y.W., MA J.H., ZHANG W.P. The critical role of local policy effects in arid watershed groundwater resources sustainability: A case study in the Minqin oasis, China. J. Sci. Total. Environ. 601 (2017), 1084, 2017.

43. CHEN L.J., FENG Q. Geostatistical analysis of temporal and spatial variations in groundwater levels and quality in the Minqin oasis, Northwest China. Environ. Earth Sci. 70 (3), 1367, 2013.

44. E,Y.H., FENG Z.D., WANG J.H., WANG Y.L., YANG Z.H. GIS-assisted FEFLOW modeling of groundwater moving processes with in the Minqin oasis in the lower reach of the Shiyang River, Northwest China. Geosci. Remote. S. 7, 4614, 2004.

45. AESCHBACH-HERTIG W., GLEESON T. Regional strategies for the accelerating global problem of groundwater depletion. Nat. Geosci. 5 (12), 853, 2012.

46. CHEN J., YIN S., GEBHARDT H., YANG X.J. Farmers' livelihood adaptation to environmental change in an arid region: A case study of the Minqin Oasis, northwestern China. Ecol. Indic. 93 (2018), 411, 2018.

47. ZHOU D.C., LUO G.P., LU L. Processes and trends of the land use change in Aksu watershed in the central Asia from 1960 to 2008. J. Arid Land. 2 (3), 157, 2010.

48. YANG Y.C., LI J.J., CHENG F.H., JACQUIE B., LI R.C. The human mechanism research of Minqin Oasis change in the lower reaches of the Shiyang River. Int. J. Appl. Geo. Research. 21 (4), 449, 2002.

49. DING W.G., YU H.L., ZHAO C., XU H., CHEN L.Z., XU L. Impacts of historical socio-economic development policies on eco-environment in great Dunhuang region of China. J. Environ. Sci. Policy. 55 (2016), 258, 2017.

50. SONG W., PIJANOWSKI B.C. The effects of China's cultivated land balance program on potential land productivity at a national scale. Appl. Geogr. 46 (46), 158, 2014.

51. ZHOU J.J., ZHANG H.W., ZHANG L.L., CAO J.J., WEI W. Spatiotemporal evolution of landscape pattern in the minqin oasis before and after implementing the comprehensive management. Arid. Z. 1 (34), 79, 2017. 
52. LI X.Y., XIAO D.N., HE X.Y., CHEN W., SONG D.M. Factors associated with farmland area changes in arid regions: a case study of the Shiyang River basin, northwestern China. Front. Ecol. Environ. 5 (3), 139, 2007.

53. MURIUKI G., SEABROOK L., MCALPINE C., JACOBSON C., PRICE B., BAXTER G. Land cover change under unplanned human settlements: a study of the Chy Hills squatters, Kenya. Landsc. Urban. Plan. 99 (2), 154, 2011.

54. TSEGAYE D., MOE S.R., VEDELD P., AYNEKULU E. Land-use/cover dynamics in Northern Afar rangelands, Ethiopia. Agric. Ecosyst. Environ. 139 (1), 174, 2010. 